\title{
Development of the State Monitoring System for large-sized Turbines Shaft Machining
}

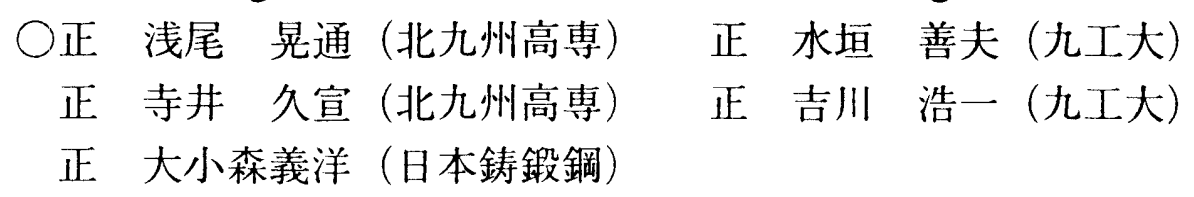

Teruyuki ASAO, Kitakyushu National College of Technology, Shii 5-20-1, Kokura-minami-ku, Kitakyushu city, Fukuoka

Yoshio MIZUGAKI, Kyushu Institute of Technology Hisanobu TERAI, Kitakyushu National College of Technology

Kouichi KIKKAWA, Kyushu Institute of Technology

Yoshihiro OHKOMORI, Japan Casting \& Forging Corporation

\section{1. 緒言}

発電用夕ービン軸や鉄龬プラント用バックアップロール $(\phi 2,000 \times 4,000)$ は「調質前加工 (切削) 」, 「調質後加 工 (切削)」,「研磨加工」,「キー溝加工」, 「センター穴加 工」，「手入加工」の工程を経る。特に調質後の外周切削は 加工時間・コスト共に全製造工程の約 30\%を占めている。 また，焼入れされた炭素龬に比べ 1.5 倍程度の硬さを持つ CrMoVNb 鋼では，工具摩耗により1回の長手切削でさえ 1 本の工具（工具交換無し）で加工が終了することは難し い. しかし，この工具の摩耗や久損（破損）が製品の寸法 確保および生産性に大きな影響を及ぼす。大型のロール旋 盤で工具交換の時期を適切に作業者に知らせることが出来 この丁程を効率良く行うことが出来れば，加工時間の短

縮, コスト低減が可能になる。

そのためには，切削状態を検出し工具交換の時期を知ら せる状態監視システムの開発が必要になる。

本報告では, 大型夕ービン用主軸加工の監視システムに おいて切削抵抗を測定する際の工具動力計の開発について 報告する。

\section{2. 加工状態監視システム}

工具摩耗を監視するには、レーザ変位計1)を用いた直接 監視法や $\mathrm{AE}^{2)}$ からの信号を処理する間接監視法3) がある. 直接監梘法は，一般的には作業を中止して測定するため時 間的ロスが生じる。また, バックアップロールの加工では

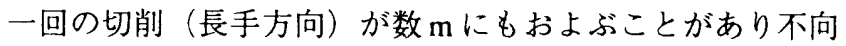
きである。間接監視法は, 工具摩耗と切削状態信号の相関 関係を得るための実験などが必要であるが，インプロセス

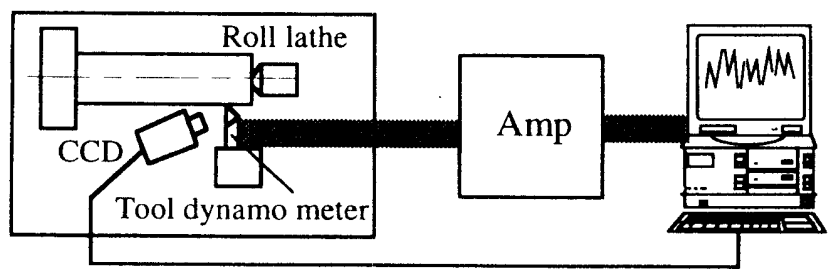

Fig.1 System configuration
で実施出来るメリットがある4)。さらには, 大型ロール旋 盤が置かれている加工現場の雲囲気（大きな切りくずや切 削油）ではレーザ変位計や AE を使って工具摩耗を測定す ることは非常に困難である。そこで本研究では，切削抵抗 を常時監視することで工具摩耗の進行を推測するためのシ ステムを開発する。

図 1 に大型タービン用主軸加工の監視システムの構成を 示す. 切削動力計からのデータは，チャージアンプを介し てパソコンに取り込まれる。また，データ収集の場合のみ CDDカメラによって工具逃げ面の摩耗量が測定される。

実際の加工では，切削抵抗のデー夕（絶対値や振幅）を実 時間で測定しこのデータを使って工具摩耗を予測し, 作業 者に工具交換の時期を知らせる。

\section{3. 歪みゲージ内蔵型工具ホルダの開発}

図 2 に本研究に使用するロール旋盤用工具ホルダの外形

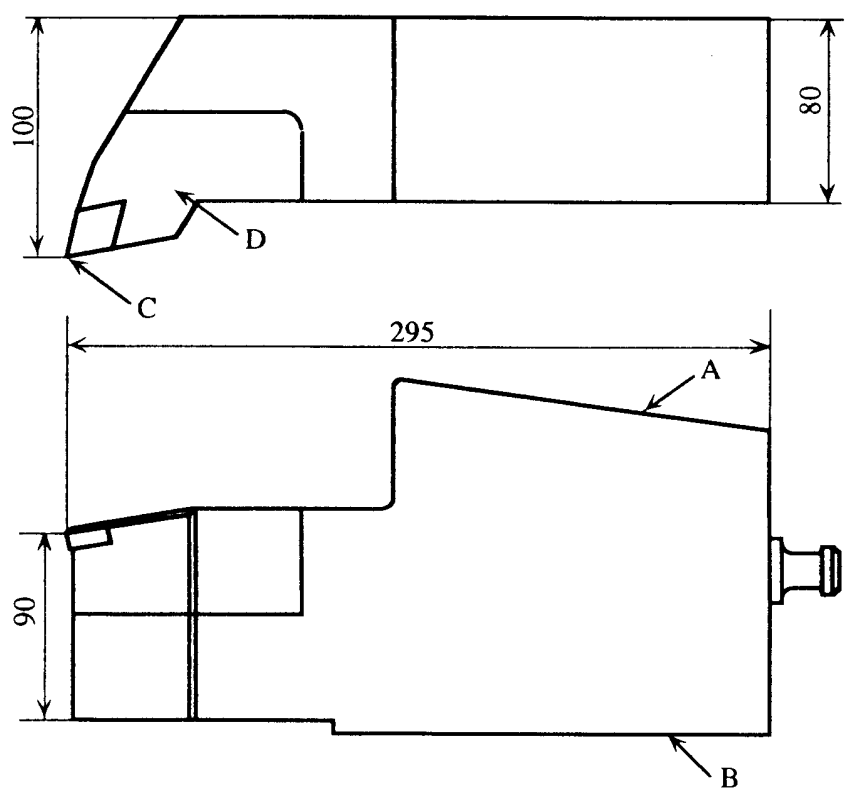

Fig.2 Configuration of tool holder 
を示す。この工具ホルダは右勝手用で左方向にオーバーハ ングした形状になっている。また，Dの部分がユニットに なっておりそこにスローアウェイチップが取り付けられる. ホルダ後方にはプルスタッドボルトがあり，刃物台とは面 A および面Bのみで固定される。なお，面Ｂには送り方 向の力を受けるためのセレーション加工が施されている。

罒に示されるように，このロール旋盤では専用の工具ホ ルダを使用しているため，市販の工具動力計を利用するこ とができない。そこでこの工具ホルダに歪みゲージを貼り 切削抵抗（主分力）を测定するが，その際工具ホルダの風 性を落とさないこと，高温の切りくずによる温度上昇を防 ぐことなどを考慮しなければならない。

今回は Autodesk 社の Mechanical Desktop で工具ホルダの 三次元形状デー夕を作成し（ユニット部は本体とボルトに よる締結のため今回は一体型としてた，切削抵抗による変 形量をDesign Space CAEにより有限要素法解析を行った。

\section{4. 解析結果}

表1工具ホルダの有限要素法解析を行うための物性值を 示す. 今回の有限要素法解析では, 節点数を 3,596 , 要素数

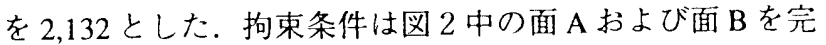
全固定とした。

切削抵抗は工具先端（図 2 中の C 点) に垂直方向（Y 軸： 主分力方向）に2,500N, 背分力 $1,250 \mathrm{~N}$, 送り分力 $1,250 \mathrm{~N}$ か かるものとして計算した。 これらの值，は加工現場と同一 条件（切込み $1.0 \mathrm{~mm}$ ，送り $0.5 \mathrm{~mm} / \mathrm{rev}$ ) で予め市販の 25 角 のバイトホルダに歪みゲージを貼り中型 CNC 旋盤を用いて 切削実験した結果を基に比切削抵抗を 5,000MPとして計算 した。

図３に工具ホルダの変形量を計算した結果を示すが，図 2 に示すユニット部での変形が約 $1.4 \mu \mathrm{m}$ となっている. 図 4, 図 5 は $\mathrm{Y}$ 軸, $\mathrm{X}$ 軸方向（背分力方向）の変形量のみ

Tab. 1 Physical properties

\begin{tabular}{|l|l|}
\hline Young's modulus & $2.0 \times 10^{11} \mathrm{~Pa}$ \\
\hline Poisson's ratio & 0.3 \\
\hline Density & $7,850 \mathrm{~kg} / \mathrm{m}^{3}$ \\
\hline Coefficient of linear thermal expansion & $1.2 \times 10^{-5} /{ }^{\circ} \mathrm{C}$ \\
\hline Coefficient of heat transfer & $60.5 \mathrm{~W} / \mathrm{m} \cdot{ }^{\circ} \mathrm{C}$ \\
\hline
\end{tabular}

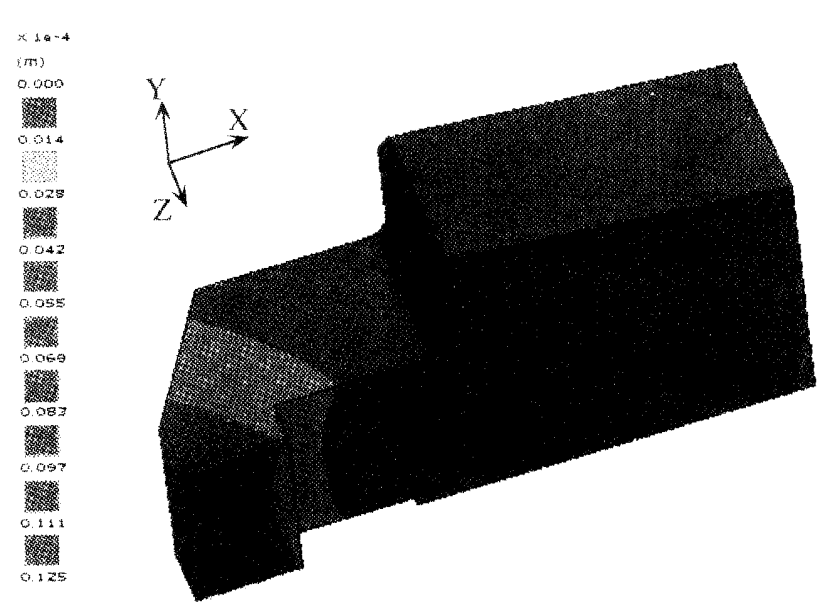

Fig3. Calculated result (resultant displacement)

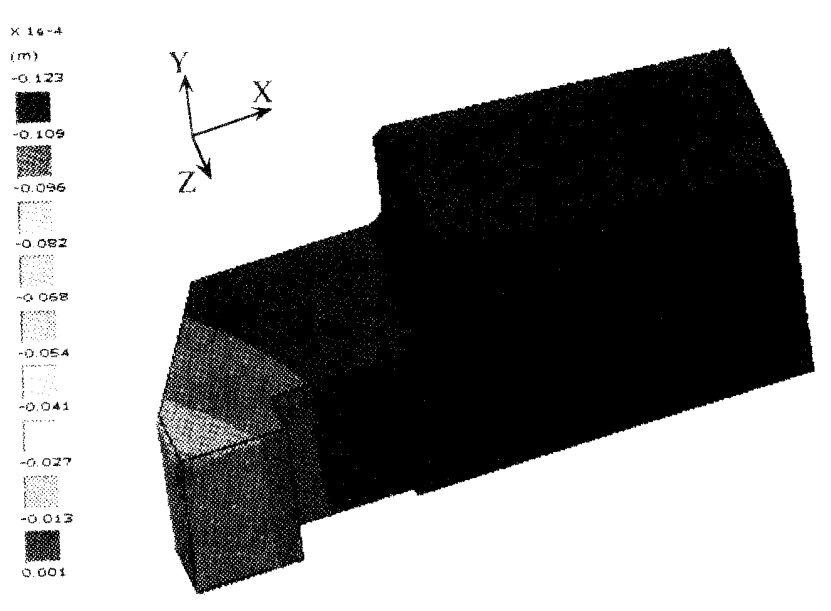

Fig4. Calculated result ( $\mathrm{Y}$ axis displacement)

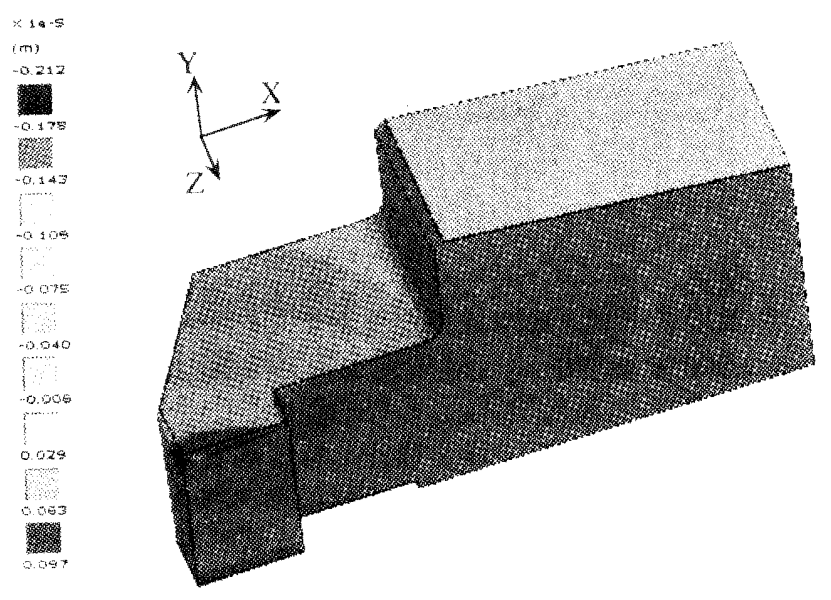

Fig5. Calculated result ( $\mathrm{X}$ axis displacement)

を表示したものである。こらの計算結果より，Y 軸方向の 変形が全体の変形とよく一致しいることがわかる。これら の計算結果は，切削抵抗を測定する際の歪みゲージ貼り付 け位置を決定する指針として活用することが出来る。

\section{5. 結言}

大型タービン用主軸加工におい切削抵抗を測定すること で加工状態を監視システムを構築することを目的に，今回 は専用のバイトホルダについて有限要素法解析を行い, 歪 みゲージ内蔵型工具ホルダの開発の指針を得た。

今後は高温の切りくずによる熱の影響やゲージの破損を 考慮して工具ホルダの改良を目指したい。

\section{【参考文献】}

1) 笠島永吉, Oleg Ryabov，森 和男：レーザセンサを用い たインプロセス工具モニタリング，日本機械学会誌（C 編), 63, 608 (1997) 1237.

2 ）小島浩二, 稲崎一郎, 三宅亮一：アコースティックエミッ ションを利用した旋削プロセスの監視，日本機械学会誌 (C 編)，52，474（1986）799.

3 ）森脇俊道, 森芳信: 二ューラルネットワークを用いた切 削状態の認識に関する研究, 精密工学会誌, 59，5（1993） 779 .

4) 松村隆, 村山孝博, 臼井英治:エンドミル加工における 工具逃げ面摩耗監視システム, 精密工学会誌, 65, 11 (1999) 1617. 